\title{
A Buying Behaviour Pattern of Modern Women
}

\author{
A.Suganya, K. Ganesamurthy
}

\begin{abstract}
:
Pearson Bryan states about the thinking style of women purchasers and the mistake done by leading brands in targeting the women buyers. He also added that the marketers concentrate on how to satisfy the female customers overall. But a female shopping cart transports not only the actual goods it also conveys tales about her long range knowledge and all the related influential factors throughout her life time. If general retailers understand this then, they could ensure the right goods are there for her and lengthen the tale. The emerging market thinks it covers all, but it misses the real women in marketing. They are the actual profit-making people for any organization. More women workforce is emerging in the recent years in all areas. They are the one making more and more money than others-Peggy Johnson. This article highlights the importance of female market and the untapped market of female Products. As women dominate the market the future focuses all the products towards the women even though the end user is male.
\end{abstract}

Index Terms: Buying Behavior, Modern Women Purchasers, Female Market.

\section{INTRODUCTION}

The economic power of the women marches towards the revolutionary Phase. It denotes the biggest opportunity for the world market. 65 percent of global spending is controlled by women which are more than 80 percent of total spending. The rise to more trillion dollars. In the globalized era the female role has changed drastically from family roles and education to environment, government, and business. And it marks the total transformation of today's women. Female buyers of all over the world have a total control over their life varieties and track. In flourishing markets, women are entering the labor force at quick speed. In this modern world Women decides most purchases do not stop with home it extended to other services as healthcare and banking. It is a challenging one for the organization to understand.

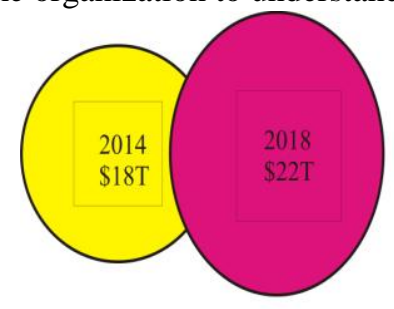

Female Income

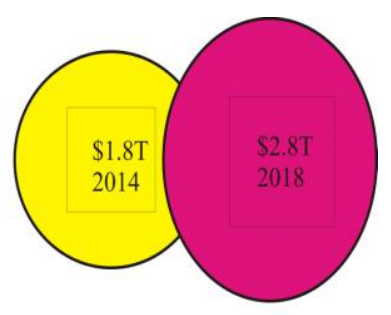

India's GDP
Revised Manuscript Received on July 05, 2019.

A.Suganya, Alagappa Institute of Management, Alagappa University, Karaikudi, Tamilnadu, India.

Dr. K. Ganesamurthy, Department of Corporate Secretaryship, Alagappa University, Karaikudi, Tamilnadu, India. global income of women was predicted by World Bank will

\section{WOMEN BEING THE DRIVERS OF WORLD ECONOMY}

Organization must learn more before marketing for women. She is not only the largest market share but also acts as an important force in encouraging from recovery and introducing new opportunity. At any point the more and more opportunity lies in base six industries. They are food, clothing, and fitness, cosmetic, health care, and financial services

\section{Food Industry}

One of the largest opportunities lies in the hands of food Industry. Female plays a very important role like lion's share in purchasing of grocery items and in preparation of meals. It is also considered as the most important budget item in the modern market which is unavoidable by everyone.

\section{Clothing Industry}

With huge room for improvement, the apparel industry burst to different colors with billion-dollar industry. With few options and sizes women feel negativity in body images. In general female buyers value their skill of buying. The general conceptual of women shop just to replace her old wardrobe with the new one has become adage. Truly women hunt cloth cloths with extra time which truly works for them in all occasions. So, there is a potential untapped market in the apparel industry. If these areas are carefully handled through new technologies in fabrication, dying, comfort and fittings they can earn a huge profit.

\section{Fitness Industry}

The biggest challenge for these Industries is it has to be accessible to all female. In common women do not prefer to push them up than in cracking a few kilos, and coup toned. Bright place, electronic wired, male dominant and complex equipment's generally do not encourage women to enter the fitness center. Now these industries keen in giving shorts with women centered firms.

\section{Cosmetics Industry}

This industry promotes an emotional welfare of women. People who spend much on cosmetics feel more comfortable and stress free than people who spend less.

This industry gives more priorities to women than men. As a consumer women are more but it is a gender dominated industry. This domination falls on men than women. Here men do trial and error version on women needs and expectation and do not understand the basic

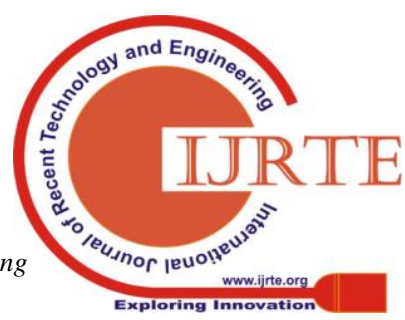


opportunity lies in this market. Because of this reason the new cosmetic products enters and moves away from this market at a quick speed. In general women are too sincere in their jobs they were especially in admittance level. But female employment drips down at the managerial and high-ranking leadership stages. The best first and foremost step toward increasing market share would be to set more women at the top. By giving importance to women the available opportunity in this industry will be best used. In which they can make important decisions and offer input about what can and cannot boom with consumers.

\section{Healthcare Industry}

Women ambiguously reported displeasure with their healthcare. They are generally dissatisfied with the waiting time and lab results time and following appointments for personally and for their family members. Generally, women

\section{Financial Service Industry}

This industry is also the least concerned for women. There are more and more opportunity to increase this industry if women are more employed. But it is also male centric industry which is too concern about the facilities to be provided for male. Once they change their approach then this can attract more of female consumers. They need to modify the quality and service provided for women

\section{Female ECONOMY}

We generally predict that the women may get settle in more important position than now not only nationally but also internationally once the dust in the economic crisis settles. It will be considered by the same fashions over the past five years. Women represent a larger proportion of the workforce. In every leading consumer company, most of the intermediate managers are women.

If only organization understand the importance of women consumers, they can visualize the greatest opportunity that lies before them in female market. Women too concern for society will also be highlighted. In this scenario, once a female

Purchase goods that do best for the world, particularly for other women. The organization which directly or indirectly encourage physical and sensitive welfare, concern over environment, offer free education and concern for the deprived, and reassure love and association.

It will be impossible to develop a common strategy to market for women. The main aim of the advertising for female is not only to appeal all female at the same time but it is to clearly specify how they reach their purchasing decision and then positioning the product accordingly. It is because of male dominant industry many strategies prepared to appeal for both gender. spend more for health care than for any other.

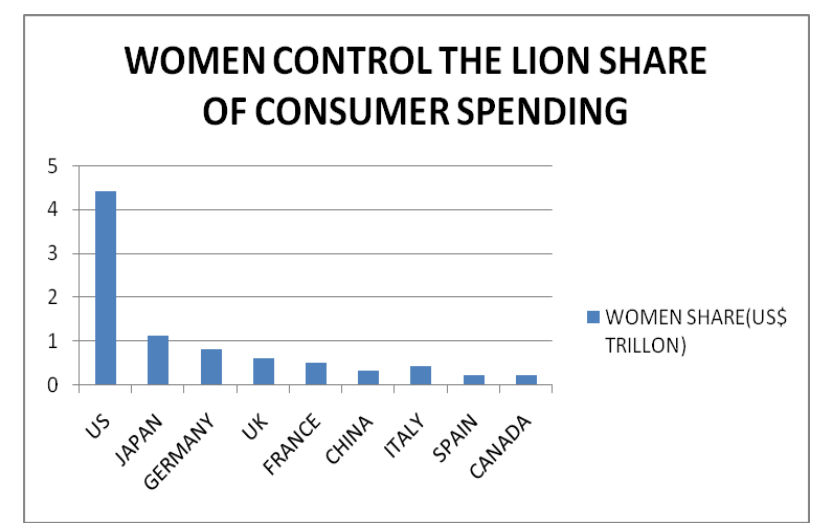

\section{TARgeting THE WOMEN CONSUMERS}

As women have a great power in dealing of products, they tend to be more and more loyal to the brands they purchase. Email and social media present the better way to receive a brand before women. The marketing mix plays an important role in tapping the right consumers. It covers visual, conversational and personal. The social media acts as active tools. The female demographic deals huge opportunity for sellers and they recognize what women expect. Brands which thought to tap female demographic should follow

\section{- Building relationships.}

Women do not purchase easily but once they are fixed with the product they develop a strong bond and emotions towards that product. They personalized, familiar and are in tune with their consciousness of the product.

- Avoid negative thoughts.

Women prefer positive and optimistic comments for the product they opted. They avoid the negative comments from the competitor's side.

- Women buying habits must be respected

Women generally analyses the product before they purchase. They do a thorough analysis, do window shopping and then they go for real purchase. Women satisfy themselves how best they choose their product when compared to competitor's product. Women will look to the meticulous details to decide about a good

\section{- Extremes to be avoided.}

Also female are easily diverted in their buying habits. Marketing campaign should be done very carefully so that the customer's perception must not be changed at any point.

\section{- Stereotypes should be avoided.}

Marketing to women consumers does not mean that it is an unchanging strategy or an extensive process it will suddenly change many women into probable customers. The main aim is to speak to their needs using their linguistic language. Marketing to female does not have to be overly complex. Marketers must know which demographic characters are more likely to attract the segment of female consumers. And tap the market accordingly. Marketing to the female is a unique and novel ways, which will help to get a more promising response from the female audience.

- Recognize women Influence

Women seek for best experiences that guide them to construct a

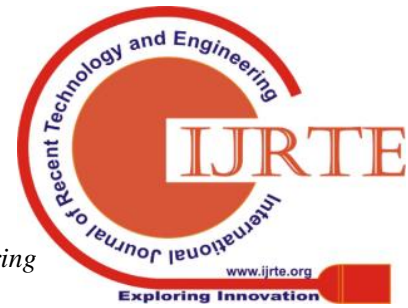


satisfying long-term relationship with the goods they choose. Women during shopping they must enjoy the product in purchasing at every level of decision-making process. They act as a brand ambassador at one point. It's new to many businesses and needs a broad shift in retail policy and plan to execute.

\section{- Formation of a female circle}

As a loyal consumer woman sees each other as experts and portraits each other as the knowledge filter.

During the complete consumer passage, female use each other as professionals and themselves as the crucial. Women are seriously influenced by other women's sentiments during the purchasing drive and they take each other as causes of advice and for instantaneous reviews of products. Because of this powerful communication, industries can swiftly decline or expand based on how they adapt to new certainties.

\section{- Knowing female similarities}

Knowing the female way of time balance, money and health care one must know the unconscious dialogue she undergone at every point in the decision-making process. Scale spends a lot of time shop with women in all types of places, in all curves of the globe. Patterns emerge from this experience. While taking decisions, for the procurements that affect more than just her, female evaluate a few collective factors in their minds: time, money, and comfort. The corporations that address these have a chance to create a tailored offering and a far improved shopping practice.

\section{- $\quad$ Respect the Differences among women}

Changing from old-fashioned "life indicators" to choose "life phases," female no longer has a lone path that expresses them. Life platforms and traditional roles have become completely varied up. Once women completed school, get married, play motherly role, bring up kids, resumed to work, and retired, all in the same order.

\section{- Join and develop with her}

The main products and services presented today assist up blank features and complimentary gestures to influence women. Making them pink color, soft in nature, feminine, fancy, relying on dated stereotypes, rather than thorough research.

\section{AUTHORITY AND DECISION-MAKING}

Variation between women and men inclines to be severe and extremely visible in power and decision-making pitches. In all societies around the globe, women hold a minority of decision-making points in public and private organizations. Advance Technology over the past two decades are apparent in all regions and in most countries, but development has been sluggish. At Present, only one in five members of minor or single houses of legislature worldwide is a female. Other contributes to this obvious under representation. Female are seldom leaders of foremost political parties, which are helpful in forming future political leaders and in associate them throughout the voting process.

\section{Woman's Need}

Brands generally try to study the female need and desire from the female customer point of view. This step is taken before they decide how to attract and withheld the prospective customers. They need to earn every female customer's goodwill.

Businesses should attempt to identify which broadcasting and mode of message does the women audience prefers. Today women just do not believe entirely watching the awareness campaign procedures and go for purchase, they study the entire market before deciding. The traditional way of marking were all worn out in today's scenario? We need to explain the products design, content, service with factual figures and tabulation. It is because the female education increased to greater extent.

Starting from planning, manufacturing, packaging, marketing brands need to concern for women consumers. Since, they are not going to be single users. Once they liked our product, they do marketing of our product that their advertisement team. So they reduce our cost and increase our market share. Female consumer's needs, wants, loves, and aspirations must be well studied by the marketers before evolving more indirect and perhaps more sophisticated 'selling' brand approaches such as labeling, limited corporate social responsibility strategies, product assignment, luxury editorials and sponsorships.

\section{GENDER DISTRIBUTION ON TWITTER}

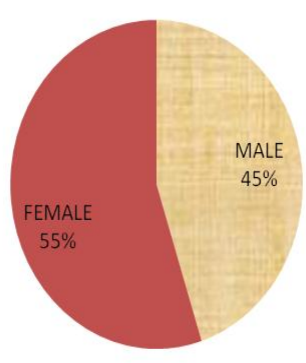

\section{SOCIAL MEDIA LEVERAGING}

Male and female shopping behavior is different. Women are not much influenced by advertisements but they do a very serious investigation about their purchase decision. According to Silverstein Michael of Boston Consulting Group, there is always a great need for a very different brand and advertising. A better use of media is needed to leverage awareness. It is a good opportunity for social media to disclose how well and best it suits female consumers. The deepness, importance and resilience of female buying power will find the future of branding, accordingly how corporations and organizations reform their selling models. Women are practical in nature, when they use social media for their investigation. Today female internet users are more than men. This in turn pave way for the importance and reach of advertisement for female users A Nielsen study shows that women surf social networking for 10 minutes while male spend a only less than 7 minutes.

For any product a great opportunity to attain the attention of the dynamic demographics is through social media. Social media is used more, will pave

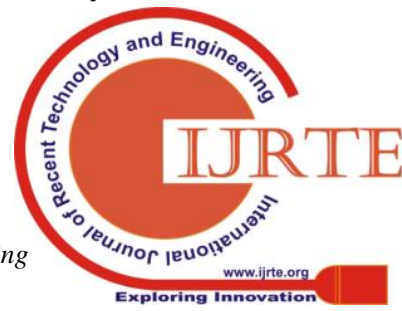


the way for a more dedicated marketing campaign.

\section{REFERENCES}

[1] Boserup, Women's Role in Economic Development, St Martin's Press, New York, 1990.

[2] Clauson, D., Bolaki, C., \& Baker, A., Apparel selection criteria related to female consumers' lifestyle, Clothing and Textiles Research Journal, 6(1), 1986, pp. 20-28. User documentation for natural language text analysis system .

[3] Bhattacharya, C.B. \& Sen, S., Consumer-company identification: a framework for understanding consumers' relationships with companies, 2003.

[4] Bakewell and Mitchell, Male versus female consumer decision making styles. Journal of Business Research, 59(12), 2006, pp.1297-1300.

[5] Bellenger, D.N. and Korgaonkar, P.K.., Profiling the recreational shopper, Journal of Retailing, 1980.

[6] Prasad, C.J. and Aryasri, A.R., Effect of shopper attributes on retail format choice behaviour for food and grocery retailing in India, International Journal of Retail \& Distribution Management, 2011.

[7] Shepherd R., Magnusson M. and Sjödén P., "Determinants of Consumer Behavior Related to Organic Foods", 34 (4/5), 2005, pp. 352-359.

[8] Sinha, P. K., \& Uniyal, D. P., Using observational research for behavioural segmentation of shoppers, Journal of Retailing and Consumer Services, 12(1), 2005, pp. 35-48

[9] Dennis, C., Women and development: what kind of development, In Ogunsheye. F.A., di Domenico, C., Dennis, C., Awosika, K. and Akinkoye, O. (eds), Nigerian Women and Development, 1996.

[10] http://www.gallup.com/businessjournal/178616/unleashing-power-pu rse.aspx,

[11] 'Unleashing the Power of the Purse' Women in the Economy, http://www.thefemalefactor.com/statistics/statistics_about_women.ht $\mathrm{ml}$ 